\title{
Optimization of the Optical Methods of Ore Grade Analysis at Mineral Processing
}

\author{
V Morozov ${ }^{1 *}$, Y Morozov ${ }^{2}$, Z Ganbaatar ${ }^{3}$ and L Delgerbat ${ }^{3}$ \\ ${ }^{1}$ Department of Mining Engineering, National University of Science and Technology MISiS, Russsia \\ ${ }^{2}$ Department of Mining Engineering, Urals State University of Mines, Russia \\ ${ }^{3}$ Department of Mining, Erdenet Mining Corporation, Mongolia
}

Submission: August 07, 2019; Published: September 26, 2019

*Corresponding author: V Morozov, Department of Mining Engineering, National University of Science and Technology MISiS, Russsia

Keywords: Grade analysis; Ore; Image recognition; Mineralogical composition; Erdenet processing plant; Ore scanning; Grinding; Optical analyzer; Copper; Molybdenum

\section{Introduction}

In-stream ore grade analysis is a new trend in effective control of ore benefication processes. On-line estimation of ore grade can be implemented based on continuous measurement of the mineralogical composition directly in-stream or using instream sampling with the following analysis. Reliable separate determination of minerals in ore is possible using modern formats of colour image recognition. The spectral characteristics of minerals in visible light are the source of information for optical spectrum-based estimation of ore mineralogical composition (Figure 1). The task of determining the grade of ore, entering processing, is to determine its similarity to the main technological types of ores [1]. The calculation of ore grade was carried out using a multi-criteria method for affiliation shares calculations.
The system mathematical model provides for calculation of the incoming ore affiliation by six (or more) significant parameters (minerals contents in the ore). At the Erdenet processing plant (Mongolia), a new facility for advanced ore diagnostics, based on optical analyzer of mineral composition, was tested. The optical spectrum-based analysis system was installed above the conveyor (Figure 2) for feeding ore to the grinding operation [2]. The ore scanning on the conveyor belt is carried out continuously. Then, using the algorithm, recognition of the ore grade is carried out. For exact analysis, the special flatbed facility was developed [3]. The measurement technique involves preparing the ore sample, forming the measurement area in the form of a flat portion of the sample, illumination and capture of the images in the visible spectrum (Figure 3).

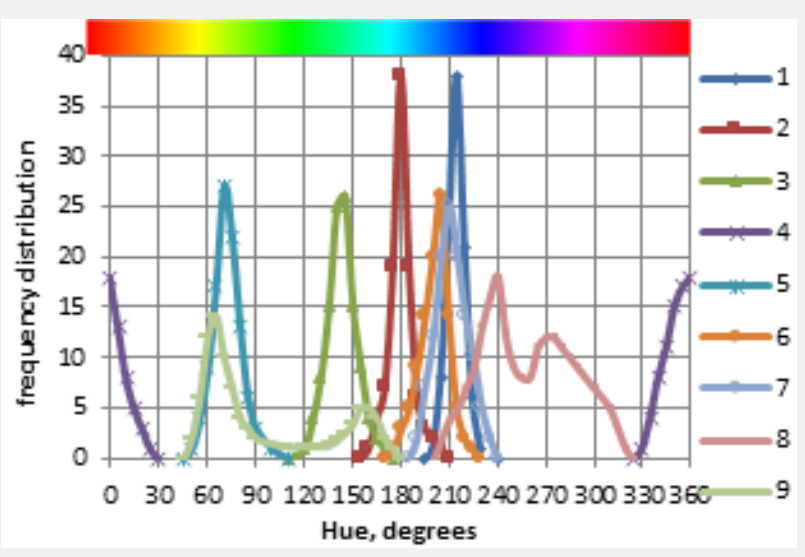

Figure 1: Color Characteristics of Minerals in HSV Format (hue): 1 - Azurite; 2 - Turquoise, 3 - Malachite; 4 - Cuprite; 5 - Chalcopyrite; 6 Chalcocite; 7 - Bornite; 8 - Covellite; 9 - Pyrite. 


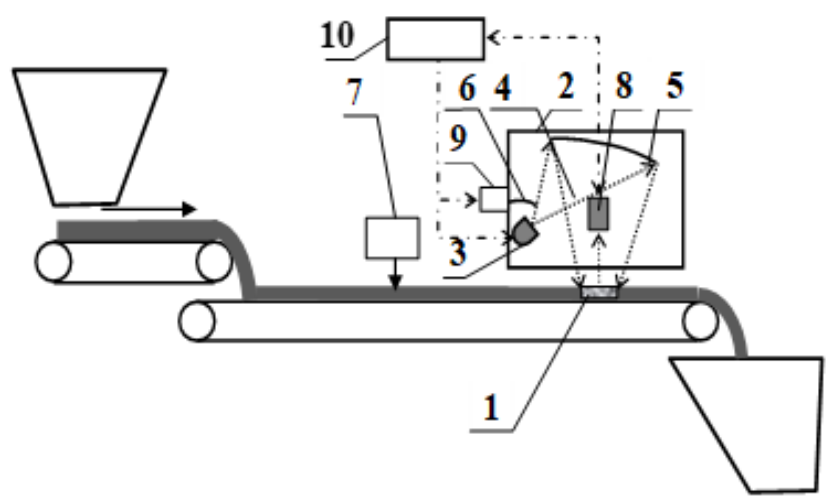

Figure 2: Facility for Telemetrically Estimation of the Ore Size and Grade: 1 - Measurement area; 2 - Case, 3 Light sources, 4 - Light flux; 5, 6 - Reflectors; 7 - Spraying apparatus; 8 - Camera; 9 - Drive; 10 - Processor.

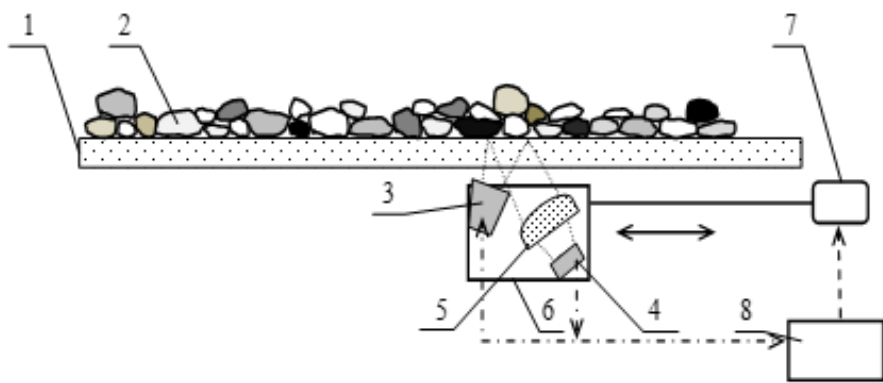

Figure 3: Design of the Flatbed facility for Optical Spectrum-based Estimation of Ore Grade: 1 - Table for Placing the Sample; 2 - Sample; 3 - Light Flux Source; 4 - Optical Converter; 5 - Optical system; 6 - Carriage; 7 - Drive; 8 - Processor.

To calculate the required parameters of grinding and flotation, special studies were carried out on the most pronounced samples of the typical ores, and the process diagrams for their grind ing and flotation were developed. The value of the pre-set function SF for each parameter of the process was calculated as a weighted average of the parameters values for each "typical" ore type (SFi) considering the contribution of the given type in the ore's mixture using Equation (1):

$$
S F=\sum \gamma_{i} S F_{i}
$$

where $\gamma \mathrm{i}$ - relative weight fraction of an ore type in the ore mixture incoming to processing. The predefined functions were used as baseline in the local systems of automatic control of grinding and flotation processes at the Erdenet processing plant. Using the procedure for ore grade determination increases the automatic control stability, as it allows a fast response to changes in the incoming ore grade. Maintaining the optimum degree of grinding and reagent consumption in the flotation provides increasing recovery of copper and molybdenum into concentrates by $0.3 \%$ and $1.1 \%$, respectively, as well as decreasing the consumption of reagents by $2-3 \%$ [4].

\section{References}

1. Morozov V, Davaasambuu D, Ganbaatar Z, Delgerbat L, Topchaev V, et al. (2013) Modern systems of automatic control of processes of grinding and flotation of copper-molybdenum ore. In: Automation in Mining, Minerals and Metal Processing, 16th IFAC Symposium, IFAC (ed.), Mission Bay, San Diego, Part 1, 46(16): 166-171.

2. Morozov V, Shek V, Morozov Y, Delgerbat L (2017) Method of photometric analysis of ore flow quality and device for its implementation.

3. Morozov V, Delgerbat L, Morozov Yu, Scheck V (2017) Method visiometrics analysis of the quality of the ore and the device for implementation.

4. Morozov V, Ganbaatar Z, Delgerbat L, Morozov Y (2018) Modern method and systems of optical ore grade analysis by processing of copper-molybdenum ores. Proceedings of IMPC, Moscow, Russia. p. 52-60. 
(C) Commons Attribution 4.0 License BY DOI: 10.19080/IMST.2019.01.555560

\section{Your next submission with Juniper Publishers}

will reach you the below assets

- Quality Editorial service

- Swift Peer Review

- Reprints availability

- E-prints Service

- Manuscript Podcast for convenient understanding

- Global attainment for your research

- Manuscript accessibility in different formats

( Pdf, E-pub, Full Text, Audio)

- Unceasing customer service

Track the below URL for one-step submission https://juniperpublishers.com/online-submission.php 